\title{
Exploring options to reduce nitrogen leaching while maintaining profitability within a Canterbury farm business comprising several distinct enterprises
}

\author{
P.C. BEUKES, T. CHIKAZHE and J.P. EDWARDS \\ DairyNZ, Private Bag 3221, Hamilton 3240, New Zealand \\ pierre.beukes@dairynz.co.nz
}

\begin{abstract}
This paper reports on a study evaluating the effects of nitrogen $(\mathrm{N})$ mitigations on $\mathrm{N}$ leaching and profitability across all hectares of a farm business consisting of a dairy platform, dairy support and beef blocks. Two different models were used, each with their own strengths and weaknesses. Mitigation options focussed on $\mathrm{N}$ fertiliser use, plantain-ryegrass-clover diverse pastures, cropping regime, and animal and feed movements between the blocks. A combination of less $\mathrm{N}$ fertiliser, replacing kale with fodder beet for wintering to reduce the crop area, an oats catch-crop following autumn-harvested fodder beet, diverse pastures on a proportion of platform and support blocks, and wintering non-pregnant cows on the beef block reduced N leaching by $19 \%$. Profitability was not affected by these mitigations. Profitability did not increase, but $\mathrm{N}$ leaching did, when changing to an all-dairy business model. Nitrogen leaching reductions can be achieved if all enterprises implement some or all of these mitigations.
\end{abstract}

Keywords: fodder beet, catch crop, modelling, all hectares, beef enterprise, cross-sectoral

\section{Introduction}

Adherence to the National Policy Statement for Fresh Water Management (NPS-FM 2014) will require farmers to reduce nitrogen $(\mathrm{N})$ leaching to improve fresh water quality. The Forages for Reduced Nitrogen Leaching (FRNL) programme was developed with the aim of providing forage technologies that will reduce nitrogen leaching by $20 \%$ whilst maintaining productivity and profitability. Previous FRNL work focused on its principles applied within the farm boundary; however, linkages exist between dairy farms, support blocks (graziers), arable and beef farms, so it is necessary to investigate the impacts of applying FRNL principles in a cross-sectoral set-up.

A mixed-enterprise farm business forming part of the FRNL monitor farm network was chosen as a case study. The business consists of a 320 ha milking platform (Ballindalloch), a 210 ha support block (Balnabreich), and a 255 ha beef farm (Beechwood); all non-contiguous blocks of land within approximately $20 \mathrm{~km}$ of each other. The properties are situated in the
Amuri basin near Culverden, in the Hurunui region of Canterbury. Currently, the baseline $\mathrm{N}$ leaching of 44 $\mathrm{kg} / \mathrm{ha}$ predicted by the Overseer ${ }^{\circledR}$ model for the dairy business (platform and support) is for the 2016-2017 season.

The aim of this study was to evaluate the effects of different options for implementing FRNL principles on $\mathrm{N}$ leaching and profitability across all hectares of a multi-enterprise farm business. Options were developed in consultation with the farmer and a community of interest.

\section{Methods}

Base and alternative scenarios

The Base scenario (our reference system) represented the current operating system for the dairy (platform and support) and the beef enterprises. The main features of the dairy system were a fully irrigated milking platform (310 ha) stocked at 3.8 crossbred cows/ha (1160 peak milking cows and 1240 wintered); standard ryegrassclover pastures fertilised at $290 \mathrm{~kg} \mathrm{~N} / \mathrm{ha}$ on the noneffluent block and $280 \mathrm{~kg} \mathrm{~N} / \mathrm{ha}$ on the 80 ha effluent block; supplements eaten of around $900 \mathrm{~kg} \mathrm{DM} /$ cow/year consisting of bought-in barley grain, palm kernel expeller, and wheat straw, with fodder beet bulb, maize silage and pasture silage made on the support block and brought to the milking platform; production of $463 \mathrm{~kg}$ milksolids (MS)/cow and $1754 \mathrm{~kg} \mathrm{MS} / \mathrm{ha}$. All wintering and rearing of young stock was done on the support block.

The beef block has an effective area of 255 ha of which 230 ha is irrigated and $200 \mathrm{~kg} \mathrm{~N}$ fertiliser/ ha applied to pastures. Cropping consists of 12 ha in dryland rape, 7 ha irrigated kale and 39 ha irrigated fodder beet. The stock included 220 non-pregnant cows, 100 coming from the milking platform plus 120 bought on the open market. The farm also raises and finishes dairy beef calves from the milking platform and some bought from the sale yards.

In all of the alternative scenarios (FRNL) a third of the platform was planted in plantain-ryegrass-clover diverse pastures. These pastures were assumed to follow the seasonal growth pattern and qualities as described by Nobilly et al. (2013) with the same grazing management as the rest of the standard pastures. The cropping regime was changed by introducing an oats 
catch-crop in FRNL-1 following fodder beet, and in FRNL-2 all kale was replaced with fodder beet, and the catch-crop only followed machine-harvested fodder beet (Table 1).

The third scenario (FRNL-3) represented a change in land use and business model for the three blocks of land, as requested by the farmer. The main drivers were an opportunity to invest and increase the long-term value of the support land, create more opportunities as part of his succession plan, increase profitability and decrease $\mathrm{N}$ leaching on all hectares. The current support block was converted to a dairy platform (DairyII), and the beef block became the support block for both the original platform (DairyI) and DairyII. DairyI grows more grass and was stocked at 3.2 cows/ ha (995 lactating cows on 310 ha, 1050 wintered) with half these cows wintered on the platform and the other half wintered on the new support block.

Conversion of DairyII was estimated to cost $\$ 2$ million in buildings, plant and machinery and vehicles, and this investment was reflected in the economic report as an increase in depreciation, debt to asset ratio and interest payments. Although both dairy platforms applied the same $\mathrm{N}$ fertiliser, DairyII was assumed to grow $2 \mathrm{t} \mathrm{DM} /$ ha less pasture than DairyI and was stocked at 3 cows/ ha (600 lactating cows on 210 ha, 630 wintered). All dry cows were wintered on DairyII on 11 ha fodder beet. Replacement stock from both DairyI and DairyII were all reared on the New Support block.

\section{Models and assumptions}

DairyNZ's Whole Farm Model (WFM), Farmax and Overseer models were used to predict the economic and environmental impact of applying FRNL principles across the three enterprises. The WFM was used in conjunction with two other linked software packages:

Table 1

Main differences between Base and alternative scenarios FRNL-1, FRNL-2, and FRNL-3. Crop areas are totals across all blocks.

\begin{tabular}{lcccc}
\hline & Base & FRNL-1 & FRNL-2 & FRNL-3 \\
\hline Plantain-diverse pasture (\%) & 0 & 30 & 30 & 30 \\
Total dairy cows wintered & 1240 & 1240 & 1240 & 1680 \\
$\mathrm{~N}$ fertiliser platform, (kg/ha) & 290 & 220 & 220 & 280 \\
$\mathrm{~N}$ fertiliser support (kg/ha) & 177 & 177 & 150 & 280 \\
$\mathrm{~N}$ fertiliser beef (kg/ha) & 200 & 200 & 200 & 130 \\
Fodder beet (ha) & 69 & 69 & 83 & 32 \\
Kale (ha) & 30 & 30 & 0 & 56 \\
Rape (ha) & 12 & 12 & 12 & 17 \\
Maize (ha) & 8 & 8 & 8 & 20 \\
Oats catch crop (ha) & 0 & 30 & 8 & 9 \\
\hline
\end{tabular}

(1) the Urine Patch Framework (UPF) that applies the urine excreted per grazing event, as predicted by the Molly cow model for individual animals, and (2) the Agriculture Production System Simulator (APSIM) that simulates water, $\mathrm{N}$ and carbon dynamics and predicts $\mathrm{N}$ leaching from urine and non-urine patches (Beukes et al. 2017). Farmax was used in conjunction with Overseer. Farmax was used to predict the economic impact and to ensure the scenarios were biologically feasible, whilst Overseer predicted $\mathrm{N}$ leaching.

The Base scenario was set up for the 2016-2017 season and the WFM and Farmax were modelled with economic input data from cash flow statements and DairyBase reports. The milk price was assumed to be $\$ 6.23 / \mathrm{kg}$ milksolids (MS). The beef farm was modelled using 2016-2017 actual stock reconciliation and farm cash flow budget. Milk and beef price sensitivities were included by changing the milk price from $\$ 6.23$ to $\$ 4.70$ and $\$ 7.70 / \mathrm{kg}$ MS, while beef purchase and sale prices were increased and decreased by $15 \%$ from the Base.

The WFM has the capability to simulate the performance of the same system under different climate years. This model was initialised with a Lismore soil for the dairy blocks and simulated for 2016-2017 with average annual drainage (135 mm), for 2015-2016 with low drainage $(70 \mathrm{~mm})$, and for 2012-2013 with high drainage $(227 \mathrm{~mm})$. Farmax-Overseer simulated an "average" year for all scenarios assuming an average pasture growth curve for the dairy platform with an annual yield of $16.9 \mathrm{t} \mathrm{DM} /$ ha (fertiliser boosted). The support block was estimated to have a pasture yield potential of approximately $1 \mathrm{t} \mathrm{DM} / \mathrm{ha}$ less than the platform and the beef block a potential of approximately 2 t DM/ha less (P. Kinney pers. comm.).

\section{Results and Discussion}

In FRNL-1 both WFM and Overseer predicted a 3\% reduction in $\mathrm{N}$ leaching (Table 2). Farmax predicted no change in operating profit (OP), while the WFM predicted a modest increase of \$200/ha. The small reduction in $\mathrm{N}$ leaching was the result of a combination of factors: 1) The diverse pastures with plantain reduced the $\mathrm{N}$ leaching on the platform, but not as much as expected because the higher yield of diverse pastures (16 t DM/ha) compared with standard pastures (14.3 t $\mathrm{DM} / \mathrm{ha}$ ) (Nobilly et al. 2013) resulted in higher intakes of relatively high crude protein (CP) grass compared with the Base; 2) The oats catch-crop following grazed fodder beet was sown in August and had low yields by early December (2-3 t DM/ha), and, consequently, had a small moderating effect on $\mathrm{N}$ leaching $(198 \mathrm{~kg}$ $\mathrm{N} /$ ha without and $156 \mathrm{~kg} \mathrm{~N} / \mathrm{ha}$ with catch-crop). In contrast, if the oats catch-crop following machineharvested fodder beet was sown in April and harvested in September then the predicted yield for this crop was 
much higher (8-12 t DM/ha), and resulted in more than $50 \%$ reduction in $\mathrm{N}$ leaching. However, because only 8 ha of fodder beet crop was machine harvested, the overall effect of this catch-crop was small.

For the FRNL-2 scenario both models predicted a further reduction in $\mathrm{N}$ leaching from FRNL-1, with WFM-Apsim predicting a $19 \%$ and Farmax-Overseer an $8 \%$ decrease compared with Base (Table 2). With only small differences in milk production between Base, FRNL-1 and FRNL-2, operating profit (OP) was similar across the three systems. The main driver of the leaching reduction in the FRNL-2 scenario was replacing kale with fodder beet for wintering, reducing the total cropping area by 16 ha because of the higher yield of fodder beet. The extra pasture area resulted in more surplus pasture exported as silage to the platform, where bought-in barley grain could be reduced. Nitrogen fertiliser use on the support block was reduced by $26 \mathrm{~kg} / \mathrm{ha}$ as there was surplus feed.

The FRNL-3 system had more cows wintered in total across all three blocks of land - 1680 versus 1240 in Base, and no beef animals carried, except weaned beef calves sold from DairyI and II. FRNL principles were still applied on both dairy platforms with a third of the pasture land comprised of diverse pastures containing plantain, and oats catch-crops following fodder beet blocks used for transition feeding and lifting of surplus fodder beet bulb. Again, both models predicted similar profitability across all hectares counted, with virtually no difference between the FRNL-3 and any of the other systems (Table 2). The gains in profit from DairyII (OP of $\sim \$ 3000 /$ ha) were basically cancelled by the low OP of the New Support block. The models predicted an average OP for the New Support block of approximately $\$ 900 / \mathrm{ha}$, reflecting the lower income from feed and grazing sold to the two dairies. Nitrogen leaching was higher than Base (Table 2), mainly because more pasture was grown across both platforms, allowing more cows to be farmed, and hence more $\mathrm{N}$ flowing through the herds and onto pastures as urinary $\mathrm{N}$. Also, the cropped area increased from 58 ha on the beef unit in Base to 93 ha on the New Support block to provide enough winter feed for half the wintered cows from DairyI and all the replacement animals from both dairies. These two factors resulted in an estimated $\mathrm{N}$ leaching of $78 \mathrm{~kg} / \mathrm{ha}$ averaged across the 3 climate years, which clearly had a negative impact on the leaching from all hectares counted.

Previous work by Beukes et al. (2017) has shown that sowing a third of a Canterbury dairy platform into diverse pastures containing plantain had a more pronounced effect on $\mathrm{N}$ leaching reduction than in the current case study. This is despite the current study showing a decrease in urinary $\mathrm{N}$ concentration of $17 \%$ when cows grazed the diverse pastures. Work by Box et al. (2016) has shown how the lower $\mathrm{N}$ and dry matter content of plantain-containing pastures, together with a possible diuretic effect, all contribute to the lower urinary $\mathrm{N}$ concentrations from cows grazing these pastures. Romera et al. (2017) has shown how important this lower urinary $\mathrm{N}$ concentration is in driving down $\mathrm{N}$ leaching. Our study emphasises a further important factor determining the efficiency of diverse pastures in lowering $\mathrm{N}$ leaching - the relative annual yield of diverse versus standard ryegrass-clover pastures on the property. In the case study quoted by Beukes et al. (2017), the standard pastures had the potential of yielding more than $20 \mathrm{t} \mathrm{DM} / \mathrm{ha}$, so when diverse pastures were introduced with an estimated yield of $17 \mathrm{t} \mathrm{DM} /$ ha for that property, total cow intake of high-CP pasture was reduced. This lower intake of pasture (standard plus diverse) resulted in the total urinary $\mathrm{N}$ load onto paddocks being less, and this along with the urine dilution effect of the plantain combined, gave substantial reductions in $\mathrm{N}$ leaching. The opposite is true in the current case study. Model-predicted standard ryegrass-clover yield was around $15 \mathrm{t} \mathrm{DM} /$ ha in the Base scenario, and the introduction of diverse pastures yielding close to $16 \mathrm{t} \mathrm{DM} / \mathrm{ha}$ in the FRNL scenarios increased the total annual intake of grass. Although the diverse pastures had a CP of around 20\%

Table 2 Predicted operating profit and nitrogen leaching for the Base and three alternative scenarios, FRNL-1, FRNL-2, and FRNL-3. The result for each scenario includes all the hectares counted for the three blocks of land totalling 775 ha. Results are presented for two different combinations of models, Farmax-Overseer ${ }^{\circledR}$, and DairyNZ's Whole Farm Model (WFM) linked to APSIM. Farmax-Overseer results are for an "average" year, while WFM-Apsim are the averages for 3 different climate years. Nitrogen leaching change from Base (\%) is in brackets.

\begin{tabular}{|c|c|c|c|c|}
\hline & & \\
\hline & Farmax-Overseer & WFM-Apsim & Farmax-Overseer & WFM-Apsim \\
\hline Base & 40 & 31 & 2462 & 2268 \\
\hline FRNL-1 & $39(-3)$ & $30(-3)$ & 2412 & 2466 \\
\hline FRNL-2 & $37(-8)$ & $25(-19)$ & 2485 & 2450 \\
\hline FRNL-3 & $48(+20)$ & $42(+35)$ & 2484 & 2368 \\
\hline
\end{tabular}


versus the $23 \%$ of standard pastures, this was largely neutralised by the higher yield, resulting in a urinary $\mathrm{N}$ load of $243 \mathrm{~kg} / \mathrm{ha} /$ year compared with the Base load of $252 \mathrm{~kg} / \mathrm{ha} /$ year. Plantain-containing pastures are most effective in mitigating $\mathrm{N}$ leaching if they reduce total annual $\mathrm{N}$ intake, and at the same time dilute the urinary $\mathrm{N}$ concentration.

The potential profitability of FRNL-3 was compared with Base by including a sensitivity of OP to different milk and beef prices. There was no difference in mean OP between the two business models ( $\$ 2411$ versus \$2414/ha for Base and FRNL-3, respectively). However, variability of OP was lower for Base versus FRNL-3 (Coefficient of Variation 36\% versus 48\%). It has been shown that, apart from total profit, variability of profit is an important consideration for many farmers (Reganold et al. 1993), with many prepared to accept a trade-off for lower, but more stable income. This outcome further supports the potential value of diversification of farm enterprises, where the risk is spread over more than one income stream, especially when dealing with a commodity like milk where world market prices have shown high volatility in the past (O'Connor \& Keane 2011). This result excludes the potential increase in land value and capital gains associated with the conversion of the support block to a dairy platform.

\section{Conclusions}

Nitrogen leaching reductions can be achieved if all enterprises implement FRNL principles. The option that resulted in the largest decrease in $\mathrm{N}$ leaching was a combination of replacing kale with fodder beet, which reduced the total cropping area, and an oats catch-crop following an autumn machine-harvested fodder beet crop. Diverse pastures containing plantain had a smaller effect, possibly because of a higher annual yield assumed for these pastures compared with the standard pastures. An alternative business model, with an objective of one dairy enterprise across all three blocks of land, resulted in no change in mean operating profit, but with a large increase in $\mathrm{N}$ leaching because of more $\mathrm{N}$ fertiliser, grass, cows and crop area. The all-dairy scenario exhibited a larger variability in operating profit compared with the mixed enterprise, with the latter showing better resilience to commodity price fluctuations.

\section{ACKNOWLEDGEMENTS}

This research was completed as part of the Forages for Reduced Nitrate Leaching programme with principal funding from the New Zealand Ministry of Business, Innovation and Employment. The programme is a partnership between DairyNZ Ltd, AgResearch, Plant \& Food Research, Lincoln University, The Foundation for Arable Research and Landcare Research.

\section{REFERENCES}

Beukes, P.C.; Edwards, P.; Coltman, T. 2017. Modelling options to increase milk production while reducing $\mathrm{N}$ leaching for an irrigated dairy farm in Canterbury. Journal of New Zealand Grasslands 79: 147-152.

Box, L.A.; Edwards, G.R.; Bryant, R.H. 2016. Milk production and urinary nitrogen excretion of dairy cows grazing perennial ryegrass-white clover and pure plantain pastures. Proceedings of the New Zealand Society of Animal Production 76: 18-21.

DairyNZ. 2018. DairyNZ Economic Survey 20162017.

Nobilly, F.; Bryant, R.H.; McKenzie, B.A.; Edwards, G.R. 2013. Productivity of rotationally grazed simple and diverse pasture mixtures under irrigation in Canterbury. Proceedings of the New Zealand Grassland Association 75: 165-171.

NPS-FM. 2014. National Policy Statement for Freshwater Management. http://www.mfe.govt.nz/ publications/fresh-water/national-policy-statementfreshwater-management-2014.

O'Connor, D.; Keane, M. 2011. Empirical issues relating to dairy commodity price volatility. pp. 63-83. In: Methods to analyse agricultural commodity price volatility. Eds. Piot-Lepetit, I.; M'Barek, R. Springer, New York, NY. https://doi. org/10.1007/978-1-4419-7634-5_5.

Reganold, J.P.; Palmer, A.S.; Lockhart, J.C.; Macgregor A.N. 1993. Soil quality and financial performance of biodynamic and conventional farms in New Zealand. Science, New Series 260: 344-349.

Romera, A.J.; Doole, G.J.; Beukes, P.C.; Mason, N.; Mudge, P.L. 2017. The role and value of diverse sward mixtures in dairy farm systems of New Zealand: An exploratory assessment. Agricultural Systems 152: 18-26. 